\title{
Teaching Space Planning and Public Senior Secondary Schools Students' Academic Performance in Education District II of Lagos State, Nigeria
}

\author{
AKINYEMI, Isiaka Adeniran, MOMOH, Yakubu Zuberu, ORUNBON, Nurudeen \\ Olalekan, FADUYILE, Grace Oluranti
}

Department of Educational Management, Lagos State University, Ojo, Lagos, Nigeria

\begin{abstract}
The study investigated the relationship between teaching space planning and students' academic performance in Lagos State senior secondary schools. The study adopted a descriptive and correlation design type. Stratified random sampling technique was used to select 300 respondents comprising principals, teachers and students from schools in Education District II of Lagos State, Nigeria. In each school, 1 principal, 4 teachers and 20 students were selected from the 12 sample schools selected for the study. Three hypotheses were formulated and to guide the study. A self-constructed questionnaire titled Teaching Space Planning Questionnaire (TSPQ) and record observation of Students' West Africa Senior School Certificate Examination (WASSCE) results of May/June from 2009-2011 were used to collect relevant data. The questionnaire was validated by experts in the field of research. The reliability coefficient of 0.78 was obtained using split-half reliability method to test the reliability of the questionnaire. Pearson's product-moment correlation statistics was used with the aid of SPSS (version 20) to test all the null hypotheses at 0.05 significance level. Analysis of data revealed that a significant relationship exists between teaching space planning, classroom planning, laboratory planning and students' academic performance in Lagos State senior secondary schools. It was recommended that government and all stakeholders should give necessary financial and professional support to the secondary schools toward ensuring good teaching space planning as this will facilitate good academic performance of the students. Furthermore, educational planners and administrators should intensify efforts at ensuring that adequate provision is made in the budget for more provision of teaching space specifically class rooms among others.
\end{abstract}

Keywords: Teaching, Space, Planning, Teaching space planning and Students' academic performance

\section{INTRODUCTION}

The school could be viewed as an organized environment where educational curricular are interpreted. It is a formal organization which serves as a transitional stage in life between family and the society (Olabode, 2002; Musa, 2004; Tabir, 2004). Meanwhile, the school plant is the totality of all things that make up a school system, as reported by Ijaduola, Oni, and Muraina (2011). However, Adeyemi (2006) also refers to school plant planning as the process of management, construction, utilization and maintenance of school facilities to ensure goal achievement. They include the sitting, the building and physical equipment, recreation places for the achievement of educational objectives, as reported by Adesina (2011).

School plant planning include teaching spaces planning, administrative places planning, circulation spaces planning, spaces for conveniences planning and accessories planning are essential in the school system. Teaching spaces such as classrooms, libraries, laboratories and technical workshops are essential in teaching-learning process. The extent to which these spaces could enhance effective teaching and learning depends on their location within the school premises, their structure and physical facilities. There is no gain saying that well planned teaching spaces in terms of location, structure and physical facilities will facilitate effective teaching and learning process and as well enhance good academic performance of the students.

According to Mark (2002), one cannot expect high level of students' academic performance where teaching space such as classrooms, libraries, technical workshops and laboratories are substandard. He emphasized that clean, quiet, safe, comfortable and healthy environment are important components of successful teaching and learning. Ajayi (2007) also maintains that high level of students' academic 
performance may not be guaranteed where teaching space such as classrooms, libraries, technical workshops and laboratories are structurally defective with poor ventilated and not spacious enough for use. He further emphasizes that structural effectiveness, proper ventilation and well located teaching space may lead to successful teaching and learning process. Therefore, the study investigates teaching space planning and public senior secondary schools students' academic performance in Education District II of Lagos State, Nigeria.

\section{Statement of the Problem}

There have been series of reports about state of facilities in Nigeria secondary schools and more worrisome is their planning. Specifically, teaching space such as classrooms, libraries, technical workshops and laboratories are structurally defective, that is, classrooms are not spacious enough. There are inadequate ventilation and lighting, classrooms located very close to technical workshops and main road. There are inadequacies in laboratory equipment and workshops while furniture, fittings and tools are not provided. These inadequacies may make teaching and workshops to be jeopardized while furniture, fittings and tools are not provided. These inadequacies may not make teaching and learning conducive, hence good academic performance of the students may not be guaranteed. These are issues of major concern to the study.

\section{Purpose of The Study}

The purpose of this study was to examine the relationship between teaching space planning and public senior secondary schools students' academic performance in Education District II of Lagos State, Nigeria. To this end, the purposes of this study were as follows.

- To find out the relationship between teaching space planning such as classrooms, libraries, technical workshops and laboratories and students' academic performance in Lagos State senior secondary schools.

- To find out the extent to which the availability of teaching space affect academic students' performance in West Africa Senior School Certificate Examination (WASSCE) in Lagos State senior secondary schools.

- To investigate whether students' academic performance is related to each of planning of classrooms and laboratories.

\section{RESEARCh Questions}

The research questions generated for this study were:

Does teaching space planning have any relationship with students' academic performance?

Can effective classroom planning enhance students' academic performance?

What is the relationship between laboratory planning and students' academic performance?

\section{RESEARCH HYPOTHESES}

The following hypotheses guided this study:

$\mathrm{Ho}_{1}$ : There is no significant relationship between teaching space planning and students' academic performance

$\mathrm{Ho}_{2}$ : There is no significant relationship between classroom planning and students' academic performance.

$\mathrm{Ho}_{3}$ : There is no significant relationship between laboratory planning and students' academic performance.

\section{SigNifiCANCE OF THE STUdY}

The results of this study will help government, school plant planners, educational planners, teachers, and the society in general to improve quality of education and provide conducive learning environment for better academic performance of students in secondary school system. It will help school plant planners to see to the well-being of the school because the school plants will determine the out of the school and the realization of educational goal. It will also help the teachers to satisfy the future educational needs of a child and society. It is expected that the teachers as well as the educational planners would be guided against any factors that are inimical to good standard of education. It is also expected that the policy makers would be provided with relevant information needed in providing the lacked teaching space. Besides, the entire public would be guided on the area where complementary effort is actually required. It will also help the government to set up 
inspectorate team to inspect secondary schools and provide reports on how to improve teaching space planning in order to avoid waste, duplication, and misuses of scarce resource. Lastly, to avoid under and over-estimation of school project.

\section{RESEARCH METHODOLOGY}

In this study, two designs were found suitable: Correlation and descriptive. This is because on the one part, the study examines the nature of relationship among teaching space planning, classroom planning, laboratory planning and students' academic performance in senior secondary schools Lagos State. On the other hand, the study attempts a description of the existing situation regarding the state of teaching space planning to improve the students' academic performance in senior secondary schools in Lagos State.

The population of the study comprises all the students, teachers and principals in all the 38 senior secondary school in Education District II of Lagos State.

The sample of the study consists of $30 \%$ of all the 38 senior secondary schools in Lagos State Education District II. This means, twelve senior secondary schools were randomly selected using stratified sampling technique from the thirty-eight senior secondary schools in Lagos State Education District II. In each school, simple random sampling technique was adopted in the selection of the respondents. From each sampled school, twenty (20) students, one principal and four teachers formed sample size. Thus, a total number of three hundred (300) respondents were involved in the study.

A self-constructed questionnaire titled Teaching Space Planning Questionnaire (TSPQ) was used to elicit information from the principal, teachers and students on teaching space planning in senior secondary schools in Lagos State Education District II and record observation of Students' West Africa Senior School Certificate Examination (WASSCE) results of May/June from 2009-2011 were used to represent students' academic performance.

However, the questionnaire comprises two sections. Section A was designed to collect information on the personal data of the respondents while Section B contains fifteen items on teaching space planning and students' academic performance in senior secondary schools in Lagos State which was structured in line with Four point Likert Scale type and the following corresponding scores were used as rating scale for the responses: Strongly Agree (SA) 4 points; Agree (A) 3 points, Disagree (D) 2 points, Strongly Disagree (SD) 1 point respectively. The researchers visited each sampled school to administer the questionnaire on respondents in the schools under study.

Data collected were analyzed using Pearson's Product-Moment Correlation Coefficient with the aid of Statistical Package for Social Sciences (SPSS). The hypotheses formulated were tested at 0.05 level of significance.

\section{RESUltS AND FindingS}

$\mathbf{H}_{\mathbf{0} 1}$ : There is no significant relationship between teaching space planning and students' academic performance in Senior Secondary Schools.

Table1. A table showing result of relationship between teaching space planning and students' academic performance

\begin{tabular}{|l|l|c|c|}
\hline \multicolumn{2}{|c|}{} & Teaching space planning & Students' academic performance \\
\hline \multirow{2}{*}{$\begin{array}{l}\text { Teaching space } \\
\text { planning }\end{array}$} & Pearson Correlation & 1 & $.463^{* *}$ \\
\cline { 2 - 4 } & Sig. (2-tailed) & & .000 \\
\cline { 2 - 4 } & $\mathrm{N}$ & 300 & 300 \\
\hline \multirow{2}{*}{$\begin{array}{l}\text { Students' academic } \\
\text { performance }\end{array}$} & Pearson Correlation & $.463^{* *}$ & 1 \\
\cline { 2 - 4 } & Sig. (2-tailed) & .000 & 300 \\
\cline { 2 - 4 } & $\mathrm{N}$ & 300 & \\
\hline
\end{tabular}

** Correlation is significant at the 0.01 level (2-tailed)

From Table 1, the data analyzed shows a positive relationship existed between teaching space planning and academic performance of students in senior secondary schools in Lagos State. This is because the result $\mathrm{r}=0.463 ; \mathrm{p}<0.05$ indicates a significant relationship between the two variables. Hence, the hypothesis which states that there is no significant relationship between teaching space planning and academic performance of students in senior secondary schools in Lagos State is rejected. 
This implies that instructional space planning directly linked with teaching and learning process in the school system and that better teaching space planning would enhance better students' academic performance while poor teaching space planning could affect the academic performance of students negatively. The finding also corroborates Marsden, (2005), Williams, Persuad and Turner (2008), found school facilities such as classroom, library, and technical workshop were significantly related to students' academic performance in secondary schools. It is apparent that where instructional spaces are properly planned in terms of location, structure and facilities, enhanced teaching and learning will take place, thereby leading to better students' academic performance. The finding corroborates that of Agada (1994), Olutola (1989) and Umar (1976) that there is positive correlation between school plants and students' academic performance.

$\mathbf{H}_{\mathbf{0} 2}$ : There is no significant relationship between classroom planning and students' academic performance in senior secondary schools.

Table2. A table showing the result of the relationship between classroom planning and students' academic performance

\begin{tabular}{|l|l|c|c|}
\hline \multicolumn{2}{|c|}{} & Classroom planning & Students' academic performance \\
\hline \multirow{4}{*}{ Classroom planning } & Pearson Correlation & 1 & $.221^{* *}$ \\
\cline { 2 - 4 } & Sig. (2-tailed) & & .000 \\
\cline { 2 - 4 } & $\mathrm{N}$ & 300 & 300 \\
\hline \multirow{2}{*}{$\begin{array}{l}\text { Students' academic } \\
\text { performance }\end{array}$} & Pearson Correlation & $.221^{* *}$ & 1 \\
\cline { 2 - 4 } & Sig. (2-tailed) & .000 & 300 \\
\cline { 2 - 4 } & $\mathrm{N}$ & 300 & \multicolumn{2}{|c}{} \\
\hline
\end{tabular}

** Correlation is significant at the 0.01 level (2-tailed)

Table 2 shows that there is a significant relationship between classroom planning and students' academic performance in senior secondary schools in Lagos State. This because the result, $r=.221$; $\mathrm{p}<0.05$ shows a positive relationship between the two variables.

Thus, the hypothesis which states that there is no significant relationship between classroom planning and students' academic performance in Lagos State senior secondary schools is rejected. It is expected that where classrooms are properly planned in terms of location, structure and facilities, effective teaching and learning process will be enhanced thereby leading to good academic performance of the students. The finding corroborates that of Adesina (2011) that classroom design influences students' academic performance. Hence he advocates that planners should look at students' developmental needs and curriculum in order to make proper planning, re-designing and expanding classroom to those needs and requirements. This finding aligns with the studies of Adepoju and Akinwunmi (2001) which heralded the significance of school plant planning (classroom planning) in the development of an effective educational programme at all level of the educational system with particular reference to the secondary school level. Stressing the importance of classroom planning, Philip (1997) maintained that classrooms with adequate lighting and ventilation and properly located within the school, play vital role in students' academic performance.

$\mathbf{H}_{\mathbf{0} 3}$ : There is no significant relationship between laboratory planning and students' academic performance in senior secondary schools.

Table3. A table showing the result of the relationship between laboratory planning and students' academic performance

\begin{tabular}{|l|l|c|c|}
\hline \multicolumn{2}{|c|}{} & Laboratory planning & Students' academic performance \\
\hline \multirow{3}{*}{ Laboratory planning } & Pearson Correlation & 1 & $.127^{*}$ \\
\cline { 2 - 4 } & Sig. (2-tailed) & & .027 \\
\cline { 2 - 4 } & $\mathrm{N}$ & 300 & 300 \\
\hline \multirow{2}{*}{$\begin{array}{l}\text { Students' academic } \\
\text { performance }\end{array}$} & Pearson Correlation & $.127^{*}$ & 1 \\
\cline { 2 - 4 } & Sig. (2-tailed) & .027 & 300 \\
\cline { 2 - 4 } & $\mathrm{N}$ & 300 & \\
\hline
\end{tabular}

** Correlation is significant at the 0.01 level (2-tailed)

Table 3 reveals that a significant relationship exists between laboratory planning and students' academic performance in Lagos State Senior Secondary Schools. This is so because the result, $r=$ $.127, \mathrm{p}<0.05$ show a positive relationship between the two variable. 
The hypothesis which states that there is no significant relationship between laboratory planning and students' academic performance in Lagos State Senior Secondary Schools is rejected. One would expect that if laboratories are properly planned in terms of location, structure and facilities, this will translate to good academic performance of the students. Olaniyonu and Gbenu (2010) see educational facilities like laboratories to those things of education which enable a skillful teacher to achieve a level of instructional effectiveness that far exceeds what is possible when they are not provided. It must be emphasized that proper planning of the laboratories may not enhance students' academic performance if the teachers are not doing their job well. The finding contradicts that of Ajayi and Yusuf (2009) who found no significant relationship between laboratories and students' academic performance. This finding also aligns with the studies of Ayeni (2008), that laboratories are essential in the teaching and learning of science subjects in secondary schools. Olakoya (2004), Uya (2004) and Ijaduola (2007) as cited by Akinyemi (2013) contended that in an educational environment like secondary school, it is indisputable that facilities such as laboratory equipment and material have great influence in the teaching and learning process because without them the empty buildings and structures no matter how attractive they are cannot be used for educational purpose. Hence, laboratory planning is no doubt an essential part of educational planning without which students' academic performance cannot be enhanced.

\section{Conclusion}

Based on the findings of this study, it is pertinent to note that students' academic performance in Lagos State Senior Secondary Schools cannot be separated from planning of teaching space by the educational planners, school administrators as well as classroom teachers.

When teaching space is well planned and managed by the teachers, the end result is good academic performance but if poor manage the end result is otherwise. Recommendations were provided based on the result of the findings and it was established that if instructional space is well planned and managed, it will have a positive impact on students' academic performance in Lagos State Senior Secondary Schools

\section{RECOMMENDATIONS}

Having established that there is significant relationship between teaching space planning and students' academic performance and that the development of any nation depends on the quality of it students, the following recommendations were made based on the findings of this study.

$>$ The government and all stakeholders must give necessary financial and professional support to the secondary schools toward ensuring good teaching space planning as this facilitates good academic performance of the students.

$>$ Educational planners, managers and administrators should intensify efforts at ensuring that adequate provision is made in the budget for more provision of teaching space specifically classrooms.

$>$ Secondary schools should be supplied with electricity. This is essential because there are so many educative electronic gadgets that could enhance teaching and learning.

$>$ The need for teaching space maintenance should be part of the orientation programme given to students, teachers and administrators in the educational system.

$>$ Educational planners, parents, government and philanthropists must see to the well-being of the school because the output of the school system determines the future of the societies.

$>$ On a final note, government should see education as the key to human capital development and the quickest and probably the best avenue to a comfortable and rewarding life. Consequently, huge part of government's budget should be allocated for providing school facilities.

\section{REFERENCES}

[1] Adepoju, T. L., and Akinwunmi, F. S. (2001). Location of secondary schools as a factor in determining academic performance of students. Ibadan Journal of Educational Studies, 1(20; $401-412$.

[2] Adesina, O.B (2011). School Plaint Planning as A Correlate of Students' Academic Performance in South West Nigeria Secondary Schools. International Journal of Business Administration, 2 (2):41-43 
[3] Adeyemi, T. O. (2006). Managing students' crisis in secondary schools in Ekiti State, Nigeria: A critical analysis. Sokoto Educational Review, 8 (2) 43-60.

[4] Agada, C. N. (1994). School Plant and its Relationship to Pupils` Academic Performance: A case study of Selected Primary Schools in Markurdi LGA of Benue State. Unpublished B. Ed Project, University of Jos, Jos.

[5] Ajayi I. A. (2007). Issues in School Management. Lagos: Bolabay Publications.

[6] Ajayi, I. A., \& Yusuf, M. A. (2009). Instructional Space Planning and Students` Academic Performance in Southwest Nigeria Secondary Schools. Int Edu Science, Vol 1 Kamla- Raj. P.7377

[7] Akinyemi, I. A. (2013). Instructional space and students' academic performance in Lagos State Education District II. Retrieved on $30^{\text {th }}$ February, 2016. From www.academia.edu/410747 6/My_Full_M_ed_Project.

[8] Ayeni, D. O. (2008). School Plant and Students' Academic Performance in Junior Secondary School in Lagos State. Med, Thesis, Unpublished, Lagos State University, Ojo, Nigeria.

[9] Ijaduola, K. O, Oni J and Muraina K. O. (2011) Empirical Analysis of School Plant Planning as a Determinant of Secondary School Students' Academic Performance. Journal of Academic Leadership.9 (2) 1

[10] Mark, S. (2002) School Building and Students' Academic Learning Outcomes. Unpublished Manuscript. State University, New York: Stony Brook.

[11] Marsden, D. B. (2005). Relations between teacher perceptions of safe and orderly environment and student achievement among ten better-performing, high-poverty schools in one Southern California elementary school district. Unpublished Doctoral Dissertation, Pepperdine University, Malibu, California.

[12] Musa, H. B. (2004) Minister Pledges to Support Upgrading to Teachers' Skills. Vanguard Newspaper 19 (5601), Thursday, September 16, pg. 23.

[13] Olabode, J. F. (2002) Human Resources Management in Secondary Schools in Ekiti Central Senatorial District of Ekiti State. Unpublished M.Ed Dissertation, University of Ado-Ekiti.

[14] Olaniyonu, S. O. A. and Gbenu, J. P. (2010). School Plant Planning and Facilities Maintenance. Lagos, Micodex Printers.

[15] Olutola, A. D. (1989). Education facilities and students` performance in West African School Certificate Examination. International Journal of Educational Management. 7; 17-24.

[16] Philip, R. (1997) Educational Facility Age and the Academic Achievement of Upper Elementary School Students. D.Ed. Thesis, University of Georgia

[17] Tabir, A. (2004) UBE Chief Charges School Inspectors, Supervisors to Update Their Skills. Comet 6 (1938), Thursday, December 2, pg. 30.

[18] Umar, M. D. (1996). The Effects of School Physical Facilities and Location on Academic Achievements of Primary School Pupils: Qualitative Study of Ningi LGA of Bauchi State, Unpublished M.Ed Thesis, University of Jos, Jos.

[19] Williams, E., Persaud, G, \& Turner, T. (2008). In Linda, K. Lemasters (Ed). International Society for Educational Planning (ISEP). George Washington University, Washington D.C. 


\section{AUTHORS' BIOGRAPHY}

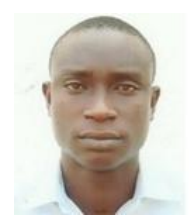

AKINYEMI, Isiaka Adeniran, was born in Lagos and had his first and second degree in Lagos State University and an NCE in Adeniran Ogunsanya College of Education respectively. He is currently a Doctoral (Ph.D.) student in Lagos State University, Lagos, Nigeria, Department of Educational Management with specialization in Educational Planning and Policy. He teaches several courses at Sandwich degree programme in Lagos State University. He is also a Part Time Lecturer in University of Ibadan in affiliation with Michael Otedola College of Primary Education, Epe, Lagos, Nigeria. He is happily married with children.

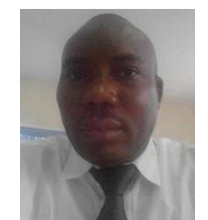

MOMOH, Yakubu Zuberu, hails from Okehi LGA of Kogi state. He obtained his first degree from university of Ilorin, Ilorin. He had his Postgraduate Diploma in Education from Abubakar Tarfawa Balewa University, Bauchi. Thereafter, a master degree in Educational Management from Lagos state university. He is currently a $\mathrm{PhD}$ student with a specialization in Educational Planning and Policy in Lagos State University. He is also a Colonel in Nigeria Army. He is happily married with children.

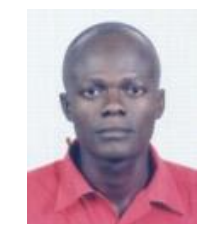

ORUNBON, Nurudeen Olalekan, holds a Nigeria Certificate in Education (NCE) at Adeniran Ogunsanya College of Education, Lagos, Nigeria, a Bachelor of Science Degree in Education and Political Science, a Master Degree in Educational Management and currently a Doctoral (Ph.D) student with specialization in Educational Administration all of Lagos State University, Ojo, Lagos, Nigeria. During his undergraduate he was a University Scholar. He teaches courses at Sandwich undergraduate degree programme in Lagos State University. He is open to any form of collaborative research. He is happily married.

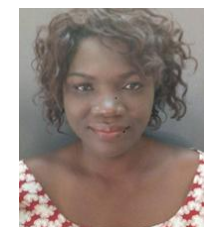

FADUYILE, Grace Oluranti, holds a Nigeria Certificate in Education, a Bachelor of Science Degree in Educational Management from University of Ado -Ekiti, Ekiti State, Nigeria, a Master of Public Administration (MPA), a Master degree in Educational Management and currently a Doctoral (Ph.D) student with specialization in Educational Administration all of Lagos State University, Nigeria. She is a seasoned teacher with over eighteen years teaching experience with Ondo State Teaching Service Commission, Ondo, Nigeria. She is happily married with children. 